\title{
PENGARUH WORK FAMILY CONFLICT DAN STRES KERJA TERHADAP KINERJA PEGAWAI WANITA PADA PUSKESMAS KECAMATAN MALANGKE BARAT KABUPATEN LUWU UTARA
}

\author{
Khaerana $^{1)}$, Amri $^{2}$ ) \\ Email: ${ }^{1)}$ khaerana.itowotu@gmail.com, ${ }^{2)}$ amriunanda09@gmail.com \\ ${ }^{1,2)}$ Fakultas Ekonomi Manajemen Univeritas Andi Djemma Palopo
}

\begin{abstract}
Abstrak
Penelitian ini bertujuan untuk mengetahui pengaruh Work Family Conflict (konflik peran ganda) dan stress kerja terhadap kinerja pegawai wanita pada Puskesmas Kecamatan Malangke Barat Kabupaten Luwu Utara dan untuk mengetahui variabel yang paling dominan berpengaruh terhadap kinerja pegawai wanita pada Puskesmas Kecamatan Malangke Barat Kabupaten Luwu Utara. Teknik pengambilan sampel dalam penelitian ini adalah non-probabilty sampling dengan menggunakan metode sensus atau sampling total, dimana semua populasi dijadikan sampel. Data dikumpulkan dengan menggunakan metode survei dengan teknik kuesioner. Jumlah responden dalam penelitian ini adalah 44 responden. Untuk menguji kualitas data dari instrumen yang digunakan dilakukan dengan uji validitas dan uji reliabilitas. Uji asumsi klasik yang terdiri dari uji normalitas, uji multikolinearitas dan uji heteroskedastisitas. Analisis regresi linear berganda, yang terdiri dari Uji koefisien determinasi $\left(R^{2}\right)$, uji simultan (Uji-F), dan uji parsial (Uji-T). Hasil penelitian menunjukkan bahwa Work Family Conflict (konflik peran ganda) dan stress kerja secara serentak (simultan) berpegaruh terhadap kinerja pegawai wanita pada Puskesmas Kecamatan Malangke Barat Kabupaten Luwu Utara dan variabel Work Family Conflict (konflik peran ganda) yang dominan berpengaruh terhadap kinerja pegawai wanita pada Puskesmas Kecamatan Malangke Barat Kabupaten Luwu Utara. Besarnya kontribusi variable Work Family conflict dan stres kerja mempengaruhi variable kinerja pegawai wanita pada Puskesmas Kecamatan Malangke Barat sebesar 0,318 atau 31,8\%, dan sisanya sebesar 68,2\% dipengaruhi oleh variable lain yang tidak diteliti dalam penelitian ini.
\end{abstract}

Keywords: Work Family Conflict, Stres Kerja, Kinerja.

\begin{abstract}
This study aims to determine the effect of Work-Family Conflict (multiple role conflict) and work stress on the performance of female employees at the Puskesmas, Malangke Barat Subdistrict, North Luwu Regency and to determine the most dominant variable influencing the performance of female employees at the Puskesmas Malangke Barat Subdistrict, North Luwu Regency. The sampling technique in this study is non-probability sampling using census or total sampling methods, where all populations are sampled. Data were collected using a survey method with a questionnaire technique. The number of respondents in this study was 44 respondents. To test the quality of the data from the instruments used, validity and reliability tests were carried out. The classic assumption test consisting of the normality test, multicollinearity test, and heteroscedasticity test. Multiple linear regression analysis, consisting of determination coefficient test (R2), simultaneous test (F-test), and partial test (Ttest). The results showed that the Work-Family Conflict (multiple role conflict) and work stress simultaneously (simultaneously) affected the performance of female employees at the Puskesmas, Malangke Barat Subdistrict, North Luwu Regency and the Work-Family Conflict variable (multiple role conflict) which had a dominant influence on the performance of female employees. at the
\end{abstract}


Puskesmas Malangke Barat Subdistrict, North Luwu Regency. The magnitude of the contribution of the Work-Family conflict variable and work stress affects the performance variable of female employees at the West Malangke District Health Center by 0.318 or $31.8 \%$, and the remaining $68.2 \%$ is influenced by other variables not examined in this study.

\section{Keywords: Work Family Conflict, Work Stress, Performance.}

\section{PENDAHULUAN}

Negara menjamin persamaan hak antara kaum pria dan wanita, sebagaimana tertuang dalam pasal 27 ayat 2 UUD 1945 yang berbunyi: "Tiap warga negara berhak atas pekerjaan dan penghidupan yang layak bagi kemanusiaan", atau dengan kata lain setiap warga negara berhak untuk mendapat pekerjaan dan penghidupan yang layak tanpa memandang jenis kelamin ataupun status sosial. Sehingga tidak heran di era sekarang ini semakin banyak wanita yang tidak hanya bekerja di sektor domestik (rumah tangga) tapi juga memanfaatkan peluang untuk bekerja di sektor publik.

Adanya tekanan dari faktor ekonomi serta keinginan psikologis untuk mengembangkan self-identity, telah mendorong wanita untuk bekerja di luar rumah, mengembangkan karir serta berpartisipasi secara aktif dalam kehidupan masyarakat (Prawitasari et al., 2007). Partisipasi wanita bukan sekedar menuntut persamaan hak tetapi juga menyatakan fungsinya mempunyai arti bagi pembangunan dalam masyarakat. Partisipasi wanita menyangkut peran tradisi dan transisi. peran tradisi mencakup peran wanita sebagai istri, ibu dan pengelola rumah tangga. Sementara Peran transisi, wanita sebagai tenaga kerja turut aktif dalam kegiatan ekonomis di berbagai kegiatan sesuai dengan keterampilan dan pendidikan yang dimiliki (Indriyani, 2009).

Menurut Istiani dalam (Buhali \& Margaretha, 2013) bahwa pekerjaan bagi seorang wanita dapat memberikan dampak positif maupun negatif. Dampak positifnya adalah melalui pekerjaannya wanita bisa membantu suami dalam hal finansial, mencari penghasilan yang layak guna menghidupi diri dan keluarganya, meningkatkan rasa percaya diri dan kesempatan mendapatkan kepuasan hidup. Sementara dampak negatif yang perlu diperhatikan, dimana tuntutan pekerjaan ini mengakibatkan ibu pulang kerja dalam keadaan lelah, sehingga tidak memiliki cukup energi untuk memenuhi kebutuhan anggota keluarganya. Sementara itu (Agustina \& Sudibya, 2018) berpendapat bahwa semakin tinggi Work family conflict yang dimiliki oleh seorang pegawai maka akan semakin menurunkan kinerjanya. Oleh Karena itu, penting untuk membangun keseimbangan yang baik antara pekerjaan dan keluarga sehingga tuntutan kedua domain tersebut bisa dipenuhi secara efisien, dan sumberdaya yang dibutuhkan dapat dicapai dan digunakan dengan mudah (Roboth, 2015).

Stres kerja dialami oleh setiap orang bisa saja berbeda. Stres ditentukan pula oleh individu itu sendiri. Reaksireaksi psikologis, fisiologis atau dalam bentuk perilaku terhadap stress adalah hasil dari interaksi situasi dengan individu, ciri-ciri kepribadian yang khusus dan pola-pola perilaku yang didasarkan pada sikap, kebutuhan nilai-nilai, pengalaman masa lalu, keadaan kehidupan dan kecakapan. Tuntutan pekerjaan, rumah tangga dan ekonomi keluarga sangat berpotensi menyebabkan wanita karir rentan mengalami stress (Potale \& Uhing, 2015).

Puskesmas Kecamatan Malangke Barat memiliki jumlah pegawai yang mayoritas wanita yang senantiasa dituntut untuk selalu berada di Puskesmas mulai pagi hingga malam hari, tentunya akan diperhadapkan dengan konflik antara perannya sebagai pegawai dan juga sebagai ibu rumah tangga, di mana kedua peran tersebut harus dilakoni dengan baik, dan sebisa mungkin tidak ada yang dikorbankan. Selain adanya work family conflict (konflik peran ganda), pegawai wanita juga akan mudah mengalami stress dikarenakan banyaknya tugas yang harus diselesaikan, baik tugas yang ada di Puskesmas maupun tugas yang harus dilakukan di rumah.

Beberapa hasil studi empiris yang telah dilakukan sebelumnya mengenai pengaruh work family conflict dan stres kerja terhadap kinerja pegawai/karyawan, ditemukan beberapa perbedaan, antara lain: penelitian yang dilakukan oleh (Indriyani, 2009) mengenai pengaruh konflik peran ganda dan stres kerja terhadap kinerja perawat wanita rumah sakit pada Rumah Sakit Roemani Muhammadiyah Semarang, menemukan bahwa Konflik peran ganda dan stres kerja berpengaruh signifikan terhadap Kinerja Perawat Wanita Rumah Sakit Roemani Muhammadiyah Semarang. Selanjutnya hasil penelitian (Roboth, 2015) tentang Analisis Work Family Conflict, Stres Kerja dan Kinerja Wanita Berperan Ganda Pada Yayasan Compassion East Indonesia, menyatakan bahwa Work Family Conflict berpengaruh signifikan terhadap kinerja wanita berperan ganda di Yayasan Compassion East Indonesia.

Stress kerja berpengaruh signifikan terhadap kinerja wanita berperan ganda di Yayasan Compassion East Indonesia. Selanjutnya temuan (Rosita, 2014) menunjukkan bahwa Konflik peran ganda dan stres kerja baik secara simultan maupun parsial berpengaruh signifikan terhadap kinerja dosen wanita pada univeritas Jambi. Sementara itu, dalam penelitian (Veliana \& Mogi, 2016) menemukan bahwa work family conflict berpengaruh negatif terhadap kinerja karyawan di Restoran The Duck King Imperial Chef Galaxy Mall, dan stres kerja tidak berpengaruh signifikan terhadap kinerja karyawan di Restoran The Duck King Imperial Chef Galaxy Mall. Dengan melihat fenomena 
tersebut di atas, maka penelitian ini bertujuan untuk menganalisis Pengaruh work family conflict dan stress kerja terhadap Kinerja pegawai wanita pada Puskesmas Kecamatan Malangke Barat Kabupaten Luwu Utara.

\section{METODE PENELITIAN}

Penelitian ini dilaksanakan pada Puskesmas Kecamatan Malangke Barat Kabupaten Luwu Utara, pada Bulan Februari - Oktober 2020. Metode penelitian ini dengan pendekatan kuantitatif dan data diperoleh melalui instrumen utama berupa kuesioner. Populasi dalam penelitian ini adalah sebanyak 44 orang pegawai wanita yang sudah menikah, dan teknik pengambilan sampelnya adalah nonprobability sampling dengan metode sensus, di mana semua populasi dijadikan sampel (Sugiyono, 2018). Data dianilisis dengan menggunakan analisis regresi berganda dan menggunkakan aplikasi SPSS versi 20, serta dengan melakukan analisis deskriptif dengan pembobotan menggunakan skala likert 1 hingga 5. Adapun alat analisis yang digunakan dalam penelitian ini adalah Analisis Regresi Linier Berganda.

\section{HASIL DAN PEMBAHASAN}

\section{Uji Validitas dan Reliabilitas}

Setelah dilakukan uji validitas dengan menggunakan SPSS 20, dan dengan membandingkan nilai $r$ hitung $>r$ tabel, untuk 9 item pernyataan pada variabel work family conflict (X1) diperoleh nilai $r$ hitung antara $(0,397-0,911)>r$ tabel $(0,304)$, sehingga dapat disimpulkan bahwa seluruh item pernyataan dinyatakan valid. Sementara untuk variabel stres kerja (X2) dengan 15 item pernyataan diperoleh nilai $r$ hitung antara $(0,423-0,754)>r$ tabel $(0,304)$ dan untuk variabel kinerja pegwai wanita (Y) dengan 12 item pernyataan dengan nilai $r$ tabel antara $(0,521-0,831)>$ $(0,304)$, jadi dengan melihat hasil perolehan nilainya maka dapat dismpulkan bahwa semua item pernyataan dinyatakan valid.

Uji reliabilitas dilakukan dengan membandingkan nilai cronbach's alpha $>0,60$, dan setelah melakukan pengujian realibilitas untuk variabel work family conflict (X1) dengan 9 item pernyataan diperoleh nilai cronbach's alpha 0,901 > 0,60 sehingga dapat disimpulkan bahwa semua pernyatannya reliabel. Sementara untuk variabel stres kerja (X2) dengan 15 item pernyataan diperoleh nilai cronbach's alpha 0,914>0,60 sehingga dimpulkan bahwa semua item pernyataan dinyatakan reliabel. Untuk variabel kinerja pegawai wanita $(\mathrm{Y})$ dengan 12 item pernyataan diperoleh nilai cronbach's alpha sebesar 0,892>0,60 sehingga dapat disimpulkan bahwa semua item pernyataan dinyatakan reliabel.

\section{Uji Asumsi Klasik}

Uji asumsi klasik merupakan persyaratan statistik yang harus dipenuhi pada analisis regresi linear berganda, dengan beberapa asumsi yang diuji, diantaranya adalah:

\section{Uji Normalitas}

Menurut Hamid, Bachri, Salju, \& Ikbal (2019), tujuan dari uji normalitas yaitu untuk menguji sebuah model regresi dimana variabel pengganggu atau residual memiliki distribusi normal. Berdasarkan hasil analisis untuk uji asumsi klasik normalitas diperoleh informasi pada Gambar 1.

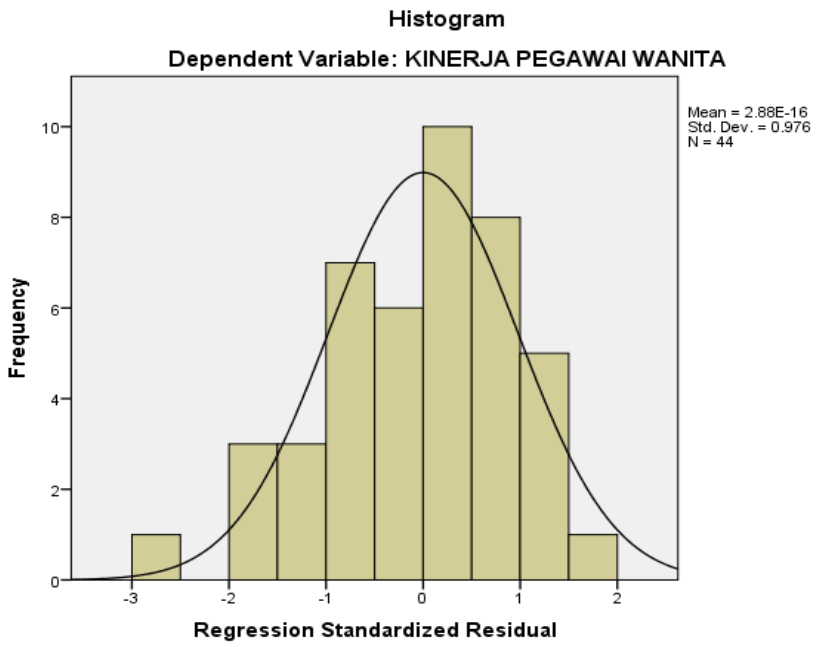

Gambar 1. Uji Normalitas

Pada diagram histogram terlihat nampak data meyebar ke kanan dan ke kiri secara merata sehingga dapat disimpulkan bahwa data terdistribusi dengan normal sehinga analisis dapat dilanjutkan.

\section{Uji Multikolinearitas}

Uji multikolinieritas bertujuan untuk menguji apakah dalam model regresi ditemukan adanya korelasi yang tinggi atau sempurna antar variabel independent. Jika antar variabel independen $\mathrm{X}$ terjadi multikolinieritas sempurna, maka koefisien regresi variabel $\mathrm{X}$ tidak dapat ditentukan dan nilai standar error menjadi tak terhingga. Jika multikoliniertias antar variabel $\mathrm{X}$ tidak sempurna tetapi tinggi, maka koefisien regresi $\mathrm{X}$ dapat ditentukan, tetapi memiliki nilai standar error tinggi yang berarti nilai koefisien regresi tidak dapat diestimasi dengan tepat (Hamid, Bachri, Salju, \& Ikbal, 2019).

Tabel 1.

Uji Multikolinieritas

\begin{tabular}{|ll|r|r|}
\hline \multirow{2}{*}{ Model } & \multicolumn{2}{|c|}{ Collinearity Statistics } \\
\cline { 2 - 3 } $1 \quad$ (Constant) & \multicolumn{1}{c|}{ Tolerance } & \multicolumn{1}{c|}{ VIF } \\
\hline & & \\
& Work Family Coflict & .660 & 1.515 \\
\multicolumn{2}{|c|}{ Stres Kerja } & .660 & 1.515 \\
\hline
\end{tabular}

Hasil uji Multikolenieritas diperoleh nilai tolerance 0,660 > 0,10 dan nilai VIF $1,515<10,00$ sehingga dapat disimpulkan bahwa tidak terjadi gejala multikolenieritas. 


\section{Uji Heterokedastisitas}

Adanya varian variabel pada model regresi yang tidak sama (konstan) merupakan indikasi adanya gejala heteroskedastisitas. Begitu juga sebalikanya apabila varian variabel pada model regresi memiliki nilai yang sama (konstan) hal ini menandakan adanya indikasi gejala homoskedastisitas. Namun yang diinginkan pada model regresi yaitu adanya gejala homoskedastisitas (Hamid, Bachri, Salju, \& Ikbal, 2019).

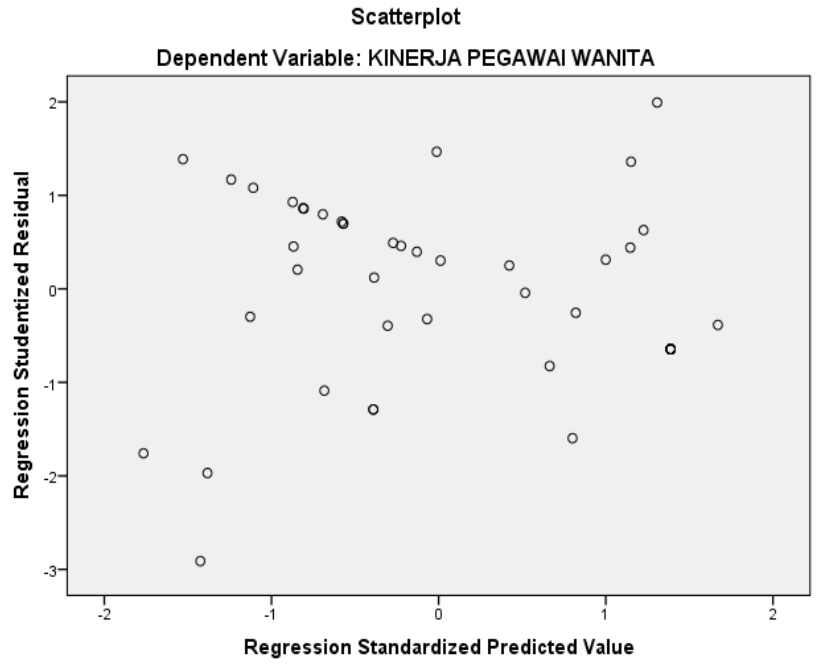

Gambar 2. Uji Heterokedastisitas

Grafik Scatterplot menunjukkan titik-titik yang penyebarannya tidak membentuk pola-pola tertentu sehingga dapat disimpulkan bahwa tidak terjadi masalah heterokedastisitas sehingga model regresi dapat terpenuhi.

\section{Uji Regresi Linear Berganda}

Uji F (Uji Simultan)

Uji $\mathrm{F}$ digunakan untuk mengetahui pengaruh variabel independen secara serentak (simultan) terhadap variabel dependen. Uji F dilakukan dengan membandingkan nilai $\mathrm{F}$ hitung dengan nilai $\mathrm{F}$ tabel atau dengan nilai signifikan < 0.05 .

Tabel 2.

Uji F (Uji Simultan)

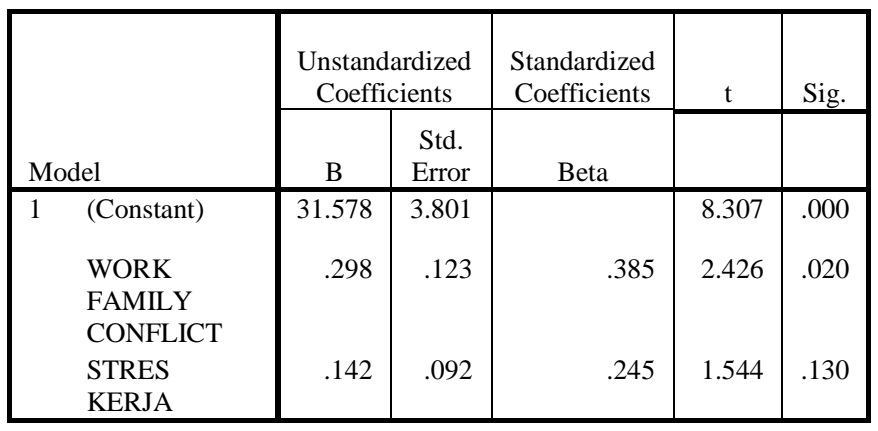

Berdasarkan table Anova tersebut di atas diperoleh nilai $\mathrm{F}$ hitung $=9,571>\mathrm{f}$ table 3,22 dan nilai signifikansi sebesar
$0,000<0,05$ sehingga dapat disimpulkan bahwa Variabel work family conflict dan stres kerja secara serentak berpengaruh terhadap kinerja pegawai wanita pada Puskesmas Kecamatan Malangke Barat Kabupaten Luwu Utara, jadi dengan demikian hipotesis pertama diterima.

\section{Uji t (Secara Parsial)}

Uji-t digunakan untuk mengetahui apakah masingmasing variabel independen secara parsial berpengaruh secara signifikan terhadap variabel dependen, dengan membandingkan nilai t-hitung > t-tabel, dan nilai signifikansi $<0.05$.

Tabel 3.

Uji t (Secara Parsial)

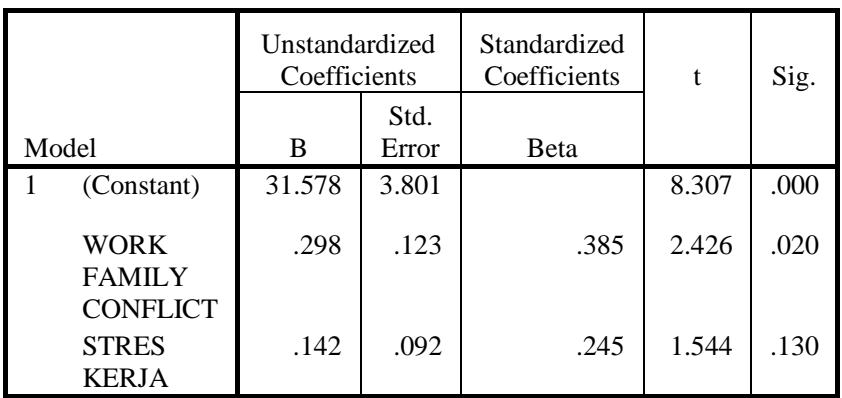

Berdasarkan tabel 3, diperoleh nilai t hitung untuk variabel work family conflict $(\mathrm{X} 1)=2,426>2,018$ dan nilai signifikansi sebesar $0,020<0,05$, jadi dapat diartikan bahwa work family conflict (X1) berpengaruh signifikan terhadap kinerja pegawai wanita (Y) pada Puskesmas Kecamatan Malangke Barat. Sementara untuk variabel stres kerja (X2) diperoleh nilai t hitung $=1,544<2,018$ dan nilai signifikansinya sebesar $0,130>0,05$, jadi dapat dimaknai bahwa stres kerja (X2) tidak berpengaruh signifikan terhadap kinerja pegawai wanita (Y) pada Puskesmas Kecamatan Malangke Barat. Berdasarkan hasil olah data tersebut di atas maka diperoleh persamaan regresi sebagai berikut:

$\mathrm{Y}=31,578+0,298 \mathrm{X} 1+\mathbf{0 , 1 4 2} \mathrm{X} 2+3.801+\mathrm{e}$

Interpretasi dari persamaan regresi linear berganda tersebut di atas dapat diuraikan sebagai berikut: nilai konstanta sebesar 31,578 menunjukkan bahwa jika variabel work family conflict dan stres kerja seluruhnya dianggap konstan atau sama dengan nol, maka kinerja pegawai wanita pada Puskesmas Malangke Barat akan tetap sebesar 31,578. Koefisien regresi untuk variabel work family conflict (X1) sebesar 0,298 menunjukkan bahwa dengan meningkatnya variabel work family conflict sebesar 1 satuan maka akan meningkatkan kinerja pegawai sebesar 0,298 dengan asumsi variabel lain tidak mengalami perubahan atau konstan. Koefisien regresi untuk variabel stres kerja (X2) sebesar 0,142 menunjukkan bahwa dengan meningkatnya variabel stres kerja 1 satuan maka akan meningkatkan kinerja pegawai sebesar 0,142 dengan asumsi variabel lain tidak mengalami perubahan atau konstan. Berdasarkan hasil 
olah data tersebut maka dapat disimpulkan bahwa variabel Work family conflict lebih dominan berpengaruh terhadap kinerja pegawai wanita, hal ini dibuktikan dengan nilai koefisien regresi lebih besar yaitu 0,298 dan nilai Standardized Coefficients beta 0,385, dengan demikian hipotesis kedua dalam penelitian ini diterima.

\section{Uji Determinasi $\left(\mathbf{R}^{2}\right)$}

Koefisien determinasi digunakan untuk mengukur seberapa besar kontribusi variabel independen (bebas) terhadap variable dependen (terikat).

Tabel 4.

Uji Determinasi $\left(\mathbf{R}^{2}\right)$

\begin{tabular}{|l|c|r|r|c|}
\hline Model & $\mathrm{R}$ & $\begin{array}{c}\mathrm{R} \\
\text { Square }\end{array}$ & $\begin{array}{c}\text { Adjusted } \\
\text { R Square }\end{array}$ & $\begin{array}{c}\text { Std. Error of the } \\
\text { Estimate }\end{array}$ \\
\hline 1 & $.564^{\mathrm{a}}$ & .318 & .285 & 4.493 \\
\hline
\end{tabular}

Berdasarkan tabel 4, model summary tersebut di atas dapat disimpulkan bahwa kontribusi variabel work family conflict dan stres kerja mempengaruhi variable kinerja pegawai wanita pada Puskesmas Kecamatan Malangke Barat sebesar 0,318 atau $31,8 \%$, dan sisanya sebesar $68,2 \%$ dipengaruhi oleh variable lain yang tidak diteliti dalam penelitian ini.

\section{PEMBAHASAN HASIL PENELITIAN \\ Pengaruh Work Family Conflict terhadap Kinerja Pegawai Wanita}

Berdasarkan hasil pengujian hipotesis, ditemukan bahwa secara bersama-sama (simultan) work family conflict dan stres kerja berpengaruh signifikan terhadap kinerja pegawai pada Puskesmas Kecamatan Malangke Barat Kabupaten Luwu Utara. Pegawai wanita pada Puskesmas Malangke Barat Kabupaten Luwu Utara sebagian besar mampu mengatur antara pekerjaan rumah tangga dengan pekerjaan kantor, karena selama ini mereka tetap mendapat dukungan dari pasangan masing-masing khususnya dalam menyelesaikan pekerjaan rumah tangga, selain itu atasan juga selalu memberi perhatian dan arahan jika pegawai kesulitan dalam menyelesakan pekerjaan kantor. Sebagaimana yang telah diungkapkan oleh Istiani dalam Buhali dan Margaretha (2013) bahwa pekerjaan bagi seorang wanita dapat memberikan dampak positif maupun negatif. Di mana dampak positifnya adalah melalui pekerjaannya wanita bisa membantu suami dalam hal finansial, mencari penghasilan yang layak guna menghidupi diri dan keluarganya, meningkatkan rasa percaya diri dan kesempatan mendapatkan kepuasan hidup. Sementara dampak negatif yang perlu diperhatikan, dimana tuntutan pekerjaan ini mengakibatkan ibu pulang kerja dalam keadaan lelah, sehingga tidak memiliki cukup energi untuk memenuhi kebutuhan anggota keluarganya. Maka dari itulah pegawai wanita diharapkan mampu untuk menyeimbangkan antara pekerjaan rumah tangga dengan pekerjaan kantor.
Hasil penelitian ini sejalan dengan hasil penelitian yang dilakukan oleh Roboth (2015) yang menyatakan bahwa work familiy konflik dan stres kerja berpengaruh signifikan terhadap kinerja karyawan, namun hal yang membedakan terletak pada objek penelitian. Senada juga dengan temuan Rosita (2014) yang menyatakan bahwa Konflik peran ganda dan stres kerja secara simultan berpengaruh terhadap kinerja dosen wanita pada Univeritas Jambi. Hasil pengujian secara parsial menunjukkan bahwa variabel work family conflict berpengaruh signifikan terhadap Kinerja pegawai wanita pada Puskesmas Kecamatan Malangke Barat. Sebagian besar pegawai wanita merasa bahwa mereka masih kurang memiliki waktu luang bersama keluarga sehingga berdampak terhadap penyelesaian pekerjaan kantor.

\section{Pengaruh Stres Kerja terhadap Kinerja Pegawai Wanita}

Sebagaimana yang dikemukakan oleh Siagian (2015) stres merupakan kondisi ketegangan yang berpengaruh terhadap emosi, jalan pikiran dan kondisi fisik seseorang. Stres yang tidak diatasi dengan baik biasanya berakibat pada ketidakmampuan seseorang berinteraksi secara positif dengan lingkungannya, baik dalam arti lingkungan pekerjaan maupun di luarnya. Hasil pengujian secara parsial menunjukkan bahwa Stres kerja tidak berpengaruh signifikan terhadap kinerja pegawai wanita. Artiya, stres kerja yang dimiliki oleh pegawai wanita belum memberi dampak yang berarti bagi peningkatan maupun penurunan kinerja pegawai wanita pada Puskesmas Kecamatan Malangke Barat.

Hasil penelitian ini sejalan dengan temuan Sutanto dan Mogi (2016) yang menemukan bahwa stres kerja tidak berpengaruh signifikan terhadap kinerja karyawan wanita di Restoran The Duck King Imperial Chef Galaxy Mall. Sementara temuan berbeda dalam penelitian yang dilakukan oleh Roboth (2015) tentang analisis work family conflict, Stres Kerja dan Kinerja Wanita Berperan Ganda Pada Yayasan Compassion East Indonesia, di mana hasil pengujian secara parsial menunjukkan variabel stres kerja berpengaruh signifikan terhadap kinerja karyawan wanita di Yayasan Compassion East Indonesia.

\section{PENUTUP}

\section{Simpulan}

Berdasarkan hasil analisis dan pembahasan, dapat disimpulkan beberapa poin sebagai berikut:

1. Secara bersama-sama (simultan) work famili conflict (konflik peran ganda) dan stres kerja berpengaruh signifikan terhadap kinerja pegawai wanita pada Puskesmas Kecamatan Malangke Barat Kabupaten Luwu Utara.

2. Secara parsial, Work family conflict berpengaruh signifikan terhadap kinerja pegawai wanita, sementara Stres kerja tidak berpengaruh sigifikan terhadap kinerja pegawai wanita pada Puskesmas Kecamatan Malangke 
Barat Kabupaten Luwu Utara.

3. Dari kedua variabel, Work family conflict lebih dominan berpengaruh terhadap kinerja pegawai wanita pada Puskesmas Kecamatan Malangke Barat Kabupaten Luwu Utara.

\section{Saran}

Berdasarkan simpulan, maka penulis menyimpulkan beberapa poin sebagai berikut:

1. Bagi Pihak Puskesmas Keamatan Malangke Barat Kabupaten Luwu Utara dalam hal ini piminan (Kepala Puskesmas), sebaiknya memperhatikan kembali jam kerja atau pun pemberian hari libur bagi setiap pegawainya agar bisa lebih meluangkan waktu dengan keluarga mereka agar hal ini tidak menyebabkan tigginya work family conflick (konflik pekerjaan dan keluarga) atau bisa disebut sebagai konflik peran ganda yang bisa berimplikasi terhadap kinerja pegawainya.

2. Pimpinan juga sebaiknya tetap menjaga hal-hal yang bisa menimbulkan stres kerja bagi pegawainya salah satunya dengan tidak memberikan beban kerja yang berlebih serta tdak membeikan pekerjaan yang tidak sesuai dengan tugas pokok dan fungsi (Tupoksi) pegawainya.

3. Bagi peneliti selanjutnya diharapkan hasil penelitian ini bisa dijadikan referensi untuk pengembangan ilmu manajemen sumber daya manusia dengan objek penelitian yang lain.

\section{DAFTAR PUSTAKA}

Agustina, R., \& Sudibya, I. G. A. (2018). PENGARUH WORK FAMILY CONFLICT TERHADAP STRES KERJA DAN KINERJA WANITA PERAWAT DI RUMAH SAKIT UMUM DAERAH PRAYA LOMBOK. E-Jurnal Ekonomi Dan Bisnis Universitas Udayana. 7(3), 775-808.

Buhali, G. A., \& Margaretha, M. (2013). Pengaruh WorkFamily Conflict Terhadap Komitmen Organisasi: Kepuasan Kerja Sebagai Variabel Mediasi. Jurnal Management Maranatha. 13(1), 15-34.

Hamid, R. S., Bachri, S., Salju, S., Ikbal, M. (2019). Panduan Praktis Ekonometrika Konsep Dasar dan Penerapan Menggunakan Eviews 10. Banten: CV. AA. RIZKY.

Indriyani, Azazah. 2009. Pengaruh Konflik Peran Ganda dan Stres Kerja terhadap Perawat Wanita Rumah Sakit (Studi pada Rumah Sakit Roemani Muhammadiyah Semarang). [Tesis]. Universitas Diponegoro Semarang. http://eprints.undip.ac.id/16657/1/AZAZAH_INDRI YANI.pdf.

Potale, R., \& Uhing, Y. (2015). PENGARUH KOMPENSASI DAN STRES KERJA TERHADAP
KEPUASAN KERJA KARYAWAN PADA PT. BANK SULUT CABANG UTAMA MANADO. Jurnal Riset Ekonomi, Manajemen, Bisnis Dan Akuntansi. 3(1), 63-73.

Prawitasari, A. K., Purwanto, Y., \& Yuwono, S. (2007). HUBUNGAN WORK-FAMILY CONFLICT DENGAN KEPUASAN KERJA PADA KARYAWATI BERPERAN JENIS KELAMIN ANDROGINI DI PT. TIGA PUTERA ABADI PERKASA CABANG PURBALINGGA. Indigenous: Jurnal Ilmiah Berkala Psikologi. 9(2), 113.

Roboth, Jane Y. 2015. Analisis Work Family Conflict, Stres Kerja dan Kinerja Wanita Berperan Ganda Pada Yayasan Compassion East Indonesia. Jurnal Riset Bisnis dan Manajemen, 3(1), 33-46.

Rosita, S. (2014). PENGARUH KONFLIK PERAN GANDA DAN STRESS KERJA TERHADAP KINERJA DOSEN WANITA DI FAKULTAS EKONOMI UNIVERSITAS JAMBI. Manajemen Bisnis. 2(2), 185-193.

Sugiyono. (2018). Metode Penelitian Kuantitatif, Kualitatif, dan R\&D. Bandung: Alfabeta.

Siagian, Sondang P. 2015. Manajemen Sumber Daya Manusia. Cetakan ke-23. Jakarta: PT. Bumi Aksara.

Sutanto, Veliana dan Mogi, Jesslyn Angelia. (2016). Analisa Work Family Conflict Terhadap Stres Kerja dan Kinerja Karyawan di Restoran The Duck King Imperial Chef Galaxy Mall Surabaya. (Jurnal Hospitality dan Manajemen Jasa), Vol 4 No. 2, 377391.

Veliana, S., \& Mogi, J. A. (2016). Analisa Pengaruh Work Family Conflict Terhadap Stres Kerja Dan Kinerja Karyawan Di Restoran the Duck King Imperial Chef Galaxy Mall Surabaya. Program Manajemen Perhotelan, Fakultas Ekonomi, Universitas Kristen Petra. 4(1), 377-391. 